\title{
CaseConnexion - udvikling af et virtuelt læringsmiljø til sygeplejestuderende
}

\section{Line Zimmer Rasmussen}

Sygeplejerske, adjunkt, cand.

cur.

University College Lillebælt

Sygeplejerskeuddannelsen Odense

Blangstedgårdsvej 4, 5220 Odense $\varnothing \varnothing$

\section{Linda Hauschildt}

\section{Nielsen}

Afdelingsleder, cand. mag, master i ikt og læring Center for Undervisningsmidler Karlavej 1, 5270 Odense N
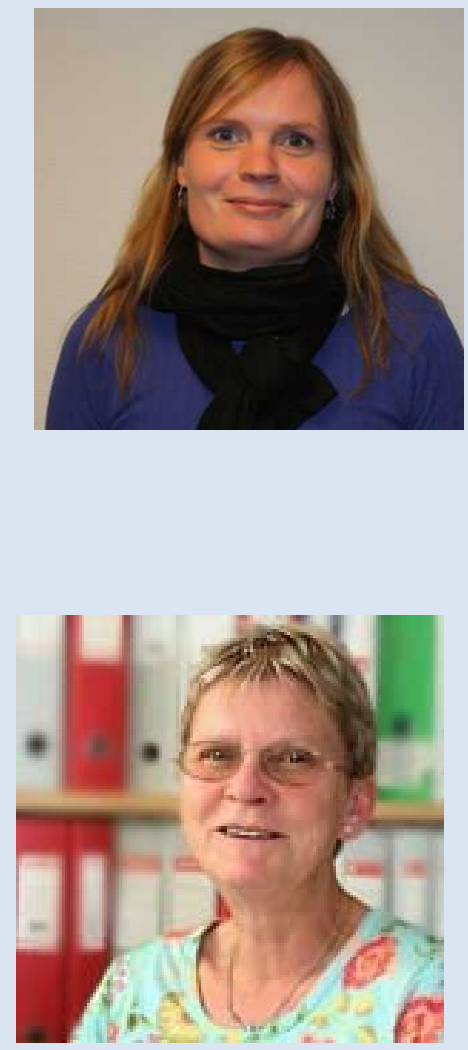


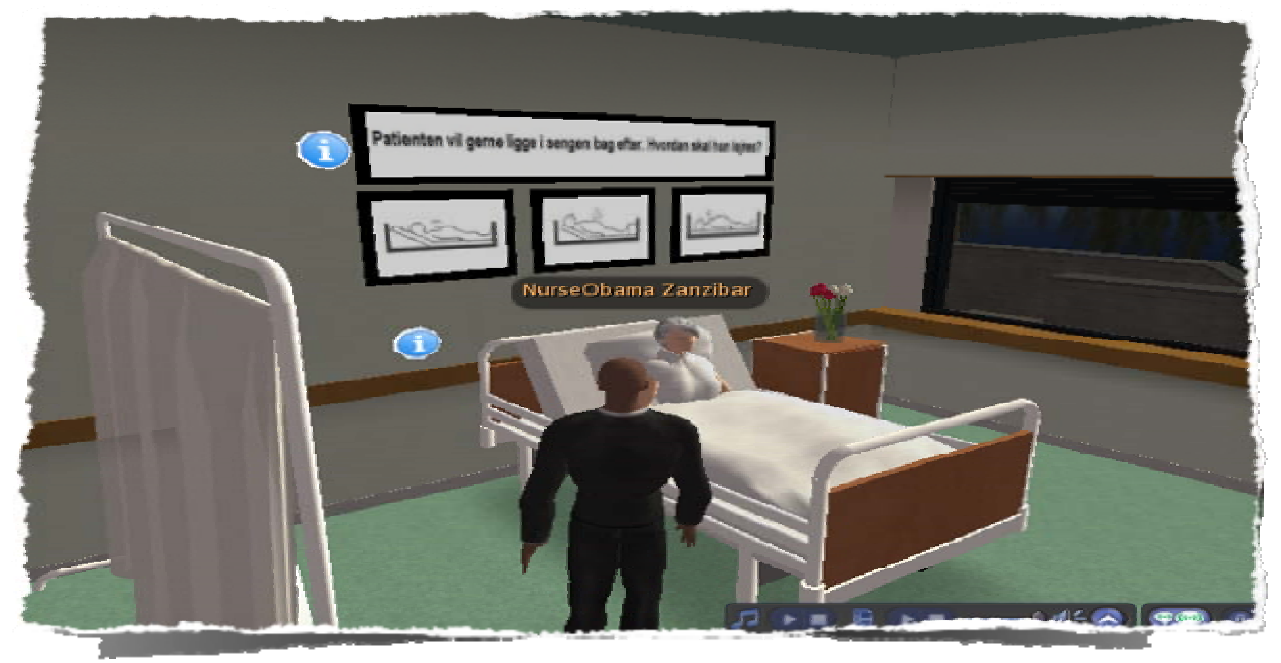

\section{Abstract}

Du møder ind i dagvagt og efter at have læst patientjournalen, går du ind på patientstuen. Foran dig $i$ hospitalssengen ligger 82-årige Fru Andersen, som har brug for din hjælp til at blive vasket - men pludselig ringer æggeuret, og du er nødt til at slukke for hospitalet og styrte ud $i$ køkkenet for at hente lasagnen ud af ovnen, inden den brænder på.

Denne lidt underlige fremtid er på vej til at blive virkelighed, for på Sygeplejerskeuddannelsen i UC Lillebælt, UC Vest og UC Syd arbejdes der med et pilotprojekt, som foregår i den online virtuelle verden, Second Life.

Formålet med artiklen er først og fremmest at videregive de erfaringer, som en projektgruppe har gjort i forbindelse med udvikling af det virtuelle læringsmiljø, CaseConnexion. Her kan sygeplejestuderende træde ind $i$ et virkelighedstro virtuelt sengeafsnit med en virtuel alter-ego som person, hvorefter der med udgangspunkt i problembaseret læring kan arbejdes med cases og øves i tilknytning til forskellige simulationer.

Det drejer det sig om at understøtte sammenhængen mellem Sygeplejerskeuddannelsens teoretiske og kliniske del gennem arbejdet med cases, hvorfor læringsmiljøets design har dette som fokus - hvordan kan interaktive elementer bidrage til, at sygeplejestuderende lærer at anvende faglige teorier og metoder til problemløsning i praksis? Gennem didaktiske 
overvejelser skitserer artiklen de principper, som designet bygger $p a ̊$, herunder hvilken betydning inddragelse af professionstænkningen har for designprincipperne.

\section{Baggrund}

Det danske uddannelsessystem står over for en gennemgribende omstillingsproces for at indstille sig på fremtidens kompetencebehov og målgrupper og de heraf afledte læringsmål, læringsformer samt læringsmidler. Fullan (1993) tegner en profil på fremtidens arbejdskraft som værende:

- folk, der kan kommunikere, tænke og blive ved at lære

- folk, der kan udvise positive holdninger og adfærd samt tage ansvar og tilpasse sig

- folk, der kan samarbejde med andre

For at nå dertil kan man med Qvortrup (1998) sige, at uddannelsessystemet overordnet skal støtte tilegnelsen af tre komponenter, nemlig det:

- at kunne forholde sig til information (meningskompetence)

- at kunne arbejde på mange forskellige måder - selvstændigt, sammen med andre, tage og dele ansvar, tage initiativ (relationskompetence)

- at kunne reflektere over processer (refleksionskompetence)

Disse krav til arbejdskraften og dermed til uddannelsessystemet synliggøres i Sygeplejerskeuddannelsen ved Bekendtgørelse om uddannelsen til professionsbachelor i sygepleje, idet uddannelsen i overensstemmelse med den samfundsmæssige, videnskabelige og teknologiske udvikling samt befolkningens behov for sygepleje, skal kvalificere den studerende inden for teoretiske og kliniske sygeplejekundskaber (Undervisningsministeriet, 2008). Gennem uddannelsen opnår den studerende personlige, praktiske og refleksive kompetencer, som indeholder elementer, der kan sammenlignes med Qvortrups. I forhold til uddannelsens faglige indhold og tilrettelæggelse lægges der eksempelvis vægt på, at varierede studieformer inddrages i uddannelsen med henblik på at

\section{"understøtte den studerendes udvikling af kompetence i forhold til læring, selvstændighed og samarbejdsevne samt evne til at skabe faglige fornyelse." \\ (Undervisningsministeriet 2008, kap. 2, §5, stk 6)}

Der henvises i Fælles National Studieordning til forskellige undervisningsog arbejdsformer i den teoretiske del af uddannelsen, herunder 
casebaseret undervisning og forskellige former for anvendelse af virtuelle læringsmiljøer, som bidrager til, at den studerende oplever sammenhæng mellem fag og fagområder samt mellem den teoretiske og kliniske undervisning. At sidstnævnte er en prioritet i uddannelsen ses desuden i Bekendtgørelse om akkreditering og godkendelse af erhvervsakademiuddannelser og professionsbacheloruddannelser, idet det her pointeres, at den studerendes læring styrkes i samspil mellem teori og praksis.(Undervisningsministeriet, 2008) Gennem en vekselvirkning mellem teoretisk og klinisk undervisning sikres praksisnærhed og udvikling af professionsrettet kompetence.

Casebaseret undervisning, der som metode kan tage udgangspunkt i problembaseret læring, giver den studerende mulighed for at arbejde kundskabsbaseret og problemorienteret. Det er ifølge Gerd Bjørke (2003) betydningsfuldt, at læringsmetode og studieformer i en uddannelse hænger sammen med de opgaver, som de studerende stilles over for som uddannede:

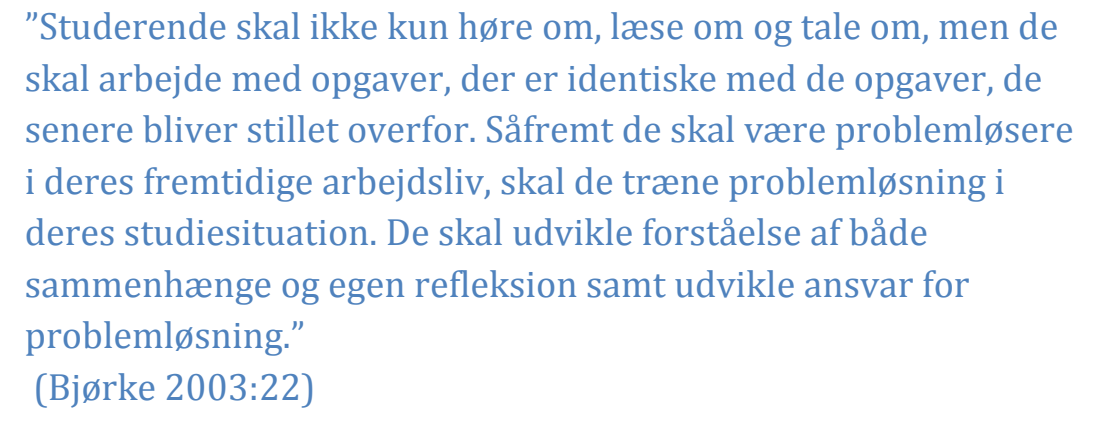

Problembaseret læring som metode giver muligheder for brug af it på måder, som er både motiverende og meningsfulde og nye strategier i forhold til anvendelse af it bliver foreslået i forhold til at uddanne studerende i et samfund i forandring (Polson, Farmer, 2002, Nichols, Renwanz-Boyle, 2001, Skiba, 2008). Integrering af it i undervisning giver mange uddannelsesmæssige fordele, når det sker på baggrund af pædagogiske overvejelser og de studerendes evne til læring understøttes i højere grad, når undervisere anvender varierede undervisnings- og arbejdsformer til at skabe læringsmiljø, så som f.eks. virtuelle (Andreasen 2002). Ved anvendelse af virtuelle læringsmiljøer som en del af uddannelsens varierede studieformer støttes den studerende desuden i at opbygge informationskompetence og it indgår i undervisningen og i læreprocesser med henblik på at understøtte og udvide forskellige former for interaktion (Undervisningsministeriet, 2008). Det kan være internt i uddannelsen samt eksternt, da et virtuelt læringsmiljø kan: 
studerende i forbindelse med personer eller kilder uden for uddannelsesverden."

(Andreasen 2002:47)

Dette indeholder muligheder for etablering af samarbejde både nationalt og internationalt.

En variation i studieformer giver endvidere mulighed for at imødekomme forskelle i de studerendes læringsstile. Den teoretiske undervisning bør derfor være sammensat af visuelle, auditive, taktile, kinæstetiske og verbaliserede elementer samtidig med at der tages højde for en analytisk eller global læringsstil - om de studerende tilegner sig viden i små bidder ad gangen eller som et samlet overblik fra starten (Lauridsen, 2007). Dette fokus på læringsstile ses desuden i Region Syddanmarks Uddannelses- og læringsstrategi, hvor øgning af kreativitet i uddannelserne er et indsatsområde. Det påpeges, at

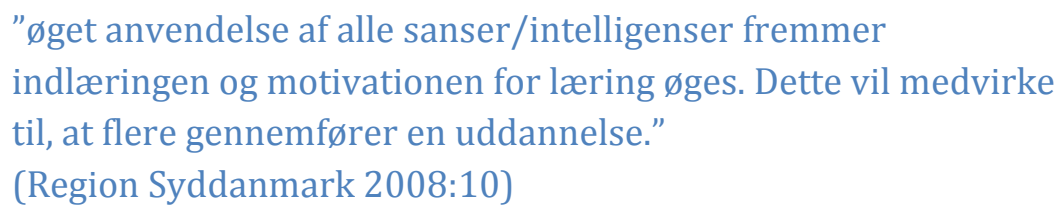

It nævnes som et element, der kan være med til at øge kreativitet og som skal medtænkes i undervisningen.

Med udgangspunkt i problembaseret læring som metode, et krav i Bekendtgørelsen om at de sygeplejestuderende udvikler informationskompetence samt et ønske om at understøtte de studerendes forskellige læringsstile ved inddragelse af mere varierede studieformer blev pilotprojektet, CaseConnexion igangsat i maj 2009, afprøves i november 2009 og evalueres i januar 2010. 


\section{Pilotprojektet som proces}

Projektet kan inddeles i tre processer:

- Opbygning og udvikling af virtuelt læringsmiljø

- Udvikling af cases til virtuelt læringsmiljø

- Afprøvning af virtuelt læringsmiljø i undervisningskontekst

De to førstnævnte processer foregår sideløbende, mens den sidste, der omhandler afprøvning, ligger i forlængelse af de andre to. Alle tre processer har dog i selve forløbet indflydelse på hinanden og er afhængige af hinanden. I disse tre processer deltager undervisere, repræsentanter fra klinikken, medarbejdere fra Center for Undervisningsmidler, Second Life developere og sygeplejestuderende.

Fire workshops er omdrejningspunktet i forhold til de tre processer. På workshop 1 og 2 deltog undervisere og kliniske vejledere og de to workshops havde følgende formål:

- Afdækning af forventninger og forestillinger om brug af virtuelt sengeafsnit i undervisning

- Tydeliggørelse af ligheder og forskelle i casebaseret undervisning på sygeplejeskoler

- Synliggørelse af problemfelter oplevet i klinikken

- Afgrænsning og beslutning om på hvilket modul cases skal anvendes

- Idégenerering og input til sygeplejefaglige cases

- Udvikling af prototype på cases, der sikrer anvendelighed i forhold til alle sygeplejeskoler

Workshop 3 og 4 havde fokus på afprøvningen af det virtuelle læringsmiljø, herunder planlægning af afprøvning lokalt i forhold til skemalægning, hold og undervisere samt introduktion til Second Life.

Sideløbende med workshops har der været et tæt samarbejde med Second Life developere med det formål at opbygge og udvikle læringsmiljøet ud fra de cases, som blev udarbejdet af den sygeplejefaglige gruppe.

De tre processer med de fire workshops som omdrejningspunkt kan ses i denne visuelle tidsplan for pilotprojektet: 


\section{Didaktiske begrundelser for valg af Second Life}

Flere tekniske platforme er overvejet til udvikling af det konkrete læringsmiljø. Valget er faldet på Second Life. Second Life er en online virtuel 3D verden, som ejes og drives af det amerikanske firma Linden Lab. Second Life blev åbnet for offentligheden i 2003 og har siden gennemgået en udvikling fra et meget omtalt socialt mødested og til et sted, hvor der eksperimenteres med de pædagogiske muligheder i en 3D virtuel verden.

Second Life er en virtuel verden, som på mange måder minder om den normale virkelighed, men uden de begrænsninger, som findes her. Second Life har ikke forud definerede mål, som man f.eks, finder det i 3D computerspil og deltagerne i Second Life opbygger selv den ramme, som den sociale interageren foregår i. Deltagerne agerer i Second Life i form af en personlig avatar. Avataren kan bevæge sig rundt i de opbyggede miljøer i Second Life og kommunikere med andre avatarer via chat eller voice. Avatarerne kan alene eller sammen med andre avatarer opbygge miljøer med landskaber, huse og interaktive faciliteter, der understøtter miljøets formål.

Miljøerne kan være åbne for alle andre avaterer, eller adgangen kan begrænses, så kun relevante avatarer har adgang.

Second Life er gratis, nemt tilgængeligt og kræver kun en computer og en internetforbindelse. Derfor vil de studerende kunne anvende miljøet uafhængig af tid og sted.

- Der kan opbygges et læringsmiljø i Second Life, der i udformning kommer meget tæt på det konkrete fysiske miljø, som de studerende møder i praksis - i dette tilfælde et sengeafsnit. 
- Den studerende kan bevæge sig rundt i miljøet i skikkelse af en personlig avatar og møde og kommunikere med andre avatarer, der også er individuelle og personlige.

- Eksterne personer med særlige faglige kompetencer kan nemt inviteres ind i miljøet i skikkelse af deres avatar og bidrage med efterspurgt viden og kompetence.

- Interaktive læringsobjekter kan relativt nemt indsættes og udskiftes i miljøet, således at der kan skabes progression i de studerendes læring.

- Der er varierede kommunikationsmuligheder, som gør det muligt at kommunikere mundtligt og/eller skriftligt i plenum, i afgrænsede grupper eller mellem enkeltpersoner.

Miljøet er fleksibelt og kan løbende justeres og tilpasses til aktuelle behov.

\section{Inspiration fra andre læringsmiljøer}

Over de seneste år har uddannelsesinstitutioner verden over vist en stigende interesse for brug af online 3D virtuelle verdener med formål knyttet til uddannelse, træning af færdigheder og brug af simulationer.

I forbindelse med opbygningen og udviklingen af CaseConnexion er der nationalt og internationalt søgt empiri udviklet af andre uddannelsesinstitutioner. Nogle af de uddannelsesinstitutioner inden for sygepleje, som er længst fremme vedr. udvikling af læringsmiljøer i Second Life, er Tacoma Community College, University of Kansas School of Nursing, University of Wisconsin Oshkosh College of Nursing og Glasgow Caledonian University School of Nursing, midwifery \& Community Health.

Der er forskel på, hvor langt udviklingen og afprøvningen er nået de forskellige steder, men samlet set tegner sig et billede af positiv respons fra undervisere og studerende. Der peges dog også på forhindringer så som stejl læringskurve i starten, når undervisere og studerende skal lære at anvende Second Life og det faktum at ikke alle studerende er positivt stemt over for brug af computere i en undervisningskontekst (Schmidt, 2009, Skiba, 2009, Warren, 2009, Hansen, 2009), hvilket der også sættes fokus på i pilotprojektet CaseConnexion.

Empirien er således løbende blevet inddraget i pilotprojektets processer med det forbehold, at der i flere undersøgelser påpeges, at udviklingen af disse læringsmiljøer stadig er på et tidligt stadie og de indeholder mange uudnyttede potentialer, der endnu mangler at blive udforsket (Hansen, 2008, Kamal, 2008, Linton et al. 2008, Sivan, 2008, Skiba, 2007). 


\section{Opbygning og udvikling af virtuelt læringsmiljø}

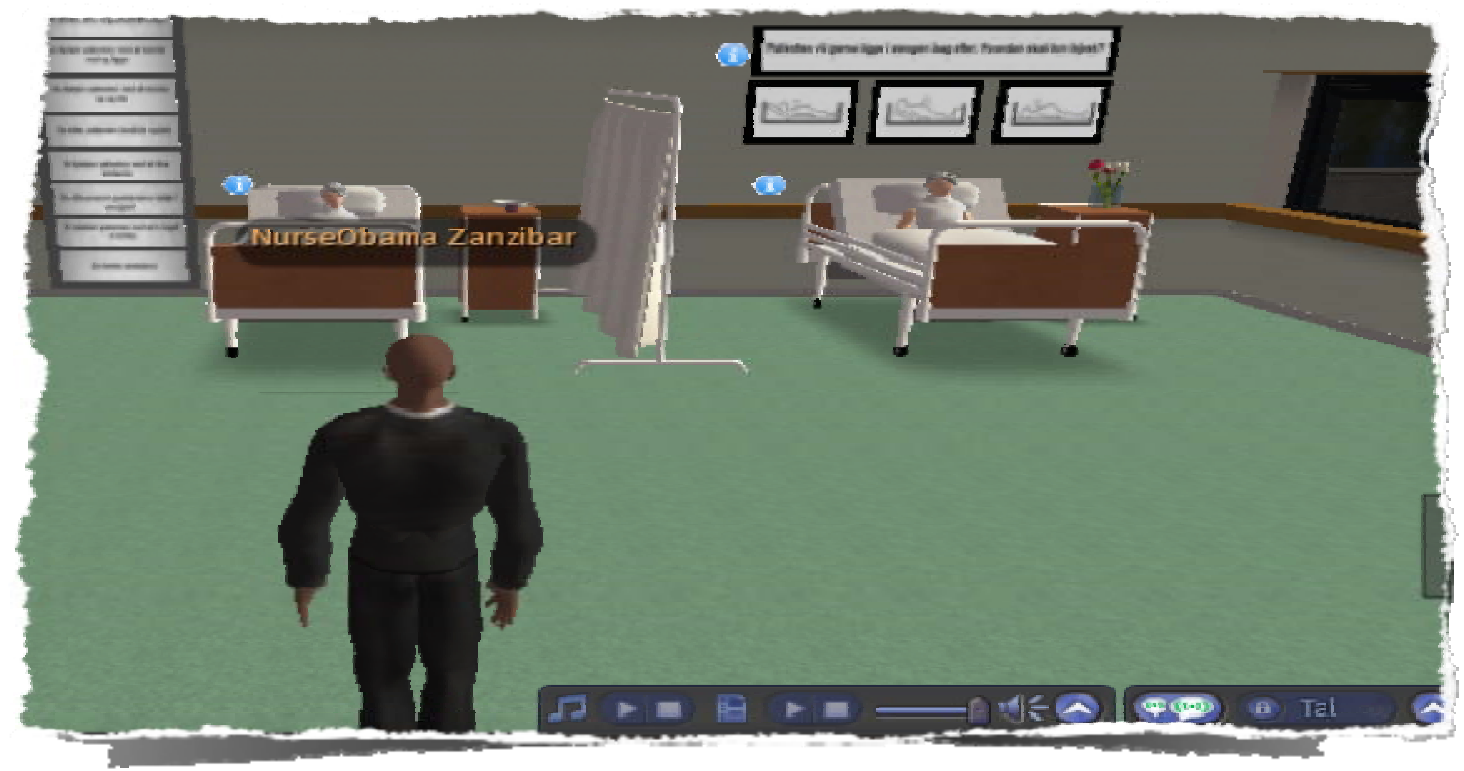

Sengeafsnittet blev opført på en ø i Second Life indkøbt til formålet og selv opbygningen blev varetaget professionelle udviklere af læringsmiljøer i Second Life. Det blev besluttet, at det virtuelle læringsmiljø skulle opbygges, så det kommer så tæt et sengeafsnit på et hospital som muligt både i udformning og i indhold, idet der ønskes et læringsmiljø, der er målrettet den profession, som de studerende er ved at uddanne sig inden for. Projektgruppen er dog opmærksom på, at sygeplejerskens virksomhedsfelt også omhandler f.eks. hjemmesygepleje og psykiatri og derfor ikke kun sygepleje på et somatisk sengeafsnit, men grundet projektets status som pilotprojekt er sengeafsnittet valgt som afgrænsning med ønske om videreudvikling.

Det blev diskuteret, om der skulle tages udgangspunkt i et helt konkret sengeafsnit på et af regionens sygehuse, men dette blev forkastet, idet sygeplejestuderende gennem uddannelsen møder mange forskellige hospitalsafdelinger, og det derfor ikke har særlig betydning for identifikationen, at det er en helt bestemt afdeling på et helt bestemt sygehus, der er opbygget. Det kan tværtimod virke forstyrrende for de studerende, som er tilknyttet andre sygehuse.

På den baggrund er der udarbejdet en skitse over et sengeafsnit, som indeholder de rum, der normalt er i et sengeafsnit, som f.eks. patientstuer, badeværelse, depot, linneddepot, skyllerum og medicinstue. Der sættes dermed fokus på genkendeligheden af rummene og deres funktion i stedet for selve sygehuset, hvilket Begg et al. (2005) fremhæver betydningen af, idet autenticiteten af læringsmiljøet og værdien af de problematikker som 
de studerende skal arbejde med, har en afsmittende effekt på motivationen for fordybelse og dermed læringsudbyttet.

Skitsen over sengeafsnittet har følgende udformning:

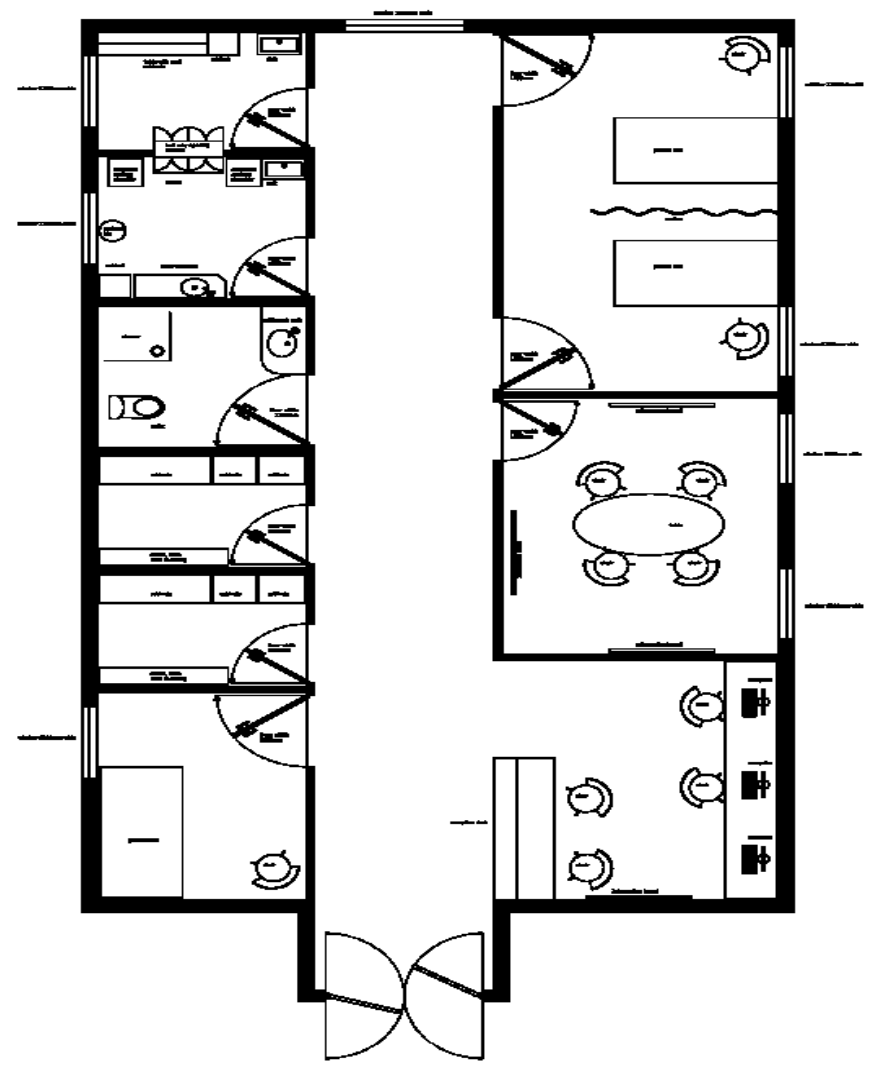

Sengeafsnittet består af

- en modtagelse og gangarealer indrettet med de faciliteter, som normalt findes i modtagelsen på et moderne sygehus. Skranke med computerarbejdspladser og telefon, sofagruppe osv. De opstillede computere fungerer interaktivt, så det er muligt at hente patientoplysninger på computeren.

- et møderum indrettet med mødebord og stole samt et antal whiteboards, hvorpå det er muligt at uploade individuelle præsentationer.

- to patientstuer med patienter. Begge stuer indeholder senge, sengeborde, håndvask og afskærmning, så indretning er genkendelig i forhold til praksis. Samtidig er der i rummet interaktive elementer, som støtter den studerendes læring og træner den studerende i de ønskede procedurer.

- skylle- og linnedrum med en række interaktive elementer, som træner den studerende i konkrete sygeplejefaglige procedurer. 
Tanken med denne opbygning er, at de sygeplejestuderende på computeren i modtagelsen kan få data om den patient, som de er tilknyttet svarende til E(lektronisk) P(atient) J(ournal). Derefter kan de gå ind på stuen, hilse på patienten og blive præsenteret for oplægget til den problemstilling, som de skal udlede og arbejde med gennem patientens kommentarer.

Med udgangspunkt i skitsen over sengeafsnittet er der dog særlige forhold, som man skal tage i betragtning i forhold til design, når avatarer i Second Life let og ubesværet skal kunne bevæge sig rundt i den virtuelle bygning og for at interaktive elementer kan fungere individuelt, ubesværet og uden at forstyrre hinanden:

- Rum og gangarealer skal være store og brede

- Der skal være højt til loftet

- Der skal være god plads mellem de enkelte elementer

\section{Udvikling af cases til virtuelt læringsmiljø}

Det bærende pædagogiske princip er, at læringsmiljøet skal lægge op til problemløsning, samarbejdende læring og vægte den studerendes læreproces. Det centrale i problembaseret læring og dermed i læringsmiljøet er udvikling af de studerendes faglige kundskaber og færdigheder i forhold til at identificere, formulere og analysere problemer i praksis i samarbejde med andre og tage reflekteret stilling til handlemuligheder og løsninger på et afklaret værdigrundlag. Det drejer sig også om, at de sygeplejestuderende udvikler nogle strategier for læring, der kan være virksomme i et langt, lærende arbejdsliv. En af de didaktiske konsekvenser er, at undervisningens fokus bliver flyttet væk fra underviserens formidling af et fagligt pensum og over på en funktionel faglighed, der lægger vægt på, at de studerende lærer at anvende faglige teorier, begreber og metoder til problemløsning i praksis.

På den baggrund har udviklingen af cases til det virtuelle sengeafsnit taget udgangspunkt i, at de studerende skal opleve, at problemet præsenteres, hvorefter de kan identificere læringsbehov, så de kan forstå, mestre og løse problemet. Der tages udgangspunkt i en problemsituation og ikke i fag. Ud fra problemsituationen kan de studerende opdage, hvilken viden og kunnen de har brug for for at kunne handle kompetent. Professionsrettet kompetence omfatter her viden, færdighed og holdning. Problemsituationen skal vække undren, da den skal danne udgangspunkt for forhold, der trænger til nærmere udredning, belysning og forståelse. De studerende arbejder eksemplarisk ud fra en problemsituation, som skal kunne bruges som eksempel for andre problemsituationer. Problemsituationen skal være så praksisnær som mulig. For sikre casens autenticitet er casen udviklet af repræsentanter fra klinisk praksis og undervisere fra Sygeplejerskeuddannelsen og det blev besluttet, at casen 
skal være kompleks med mange data og flere problemstillinger frem for en mere afgrænset case med kun et bestemt fokusområde. Begrundelsen er, at de studerende møder patienter med komplekse problemstillinger i praksis og her med hjælp fra vejleder øver sig i at afgrænse i forhold til den studerendes niveau i uddannelsen.

Den udarbejdede case til pilotprojektet retter sig mod sygeplejerskeuddannelsens modul 2, hvor delelementerne inden for professionsrettet kompetence kan betragtes som f.eks. viden om teoretiske forhold der knytter sig til grundlæggende behov med inddragelse af praksis-, udviklings- og forskningsbaseret viden samt identifikation af forhold der har betydning for patientens oplevelse af velvære knyttet til grundlæggende behov. Færdigheder ses som bl.a. argumentation for og anvendelsen af kliniske metoder knyttet til grundlæggende behov, mens holdning kan forstås som f.eks. inddragelse af sygeplejens værdigrundlag $\mathrm{i}$ samarbejdet med patienten om at udføre grundlæggende sygeplejehandlinger i forhold til de grundlæggende behov. Casen omhandler derfor en ældre dame, som indlægges pga.

vejrtrækningsbesvær. Casen strækker sig over en dagvagt, hvor patienten har behov for hjælp i forskellige situationer, så som ved kropsvask, vejrtrækningsbesvær og svimmelhed ved stillingsændring. Det er i forhold til patientens grundlæggende behov, at de studerende skal udøve sygepleje og opnå viden, færdigheder og holdning, hvilket har dannet grundlag for udvælgelsen og designet af de interaktive elementer.

\section{Fra papir til Second Life}

I første omgang blev casen udarbejdet som et tekstdokument, der efterfølgende blev splittet op og sat ind i en skabelon. Skabelonen har fungeret som styringsredskab for opbygningen af læringsmiljøet og dermed i samarbejdet mellem projektgruppe og Second Life developere. Analysen af casen med henblik på design af interaktive elementer kan illustreres på følgende måde:

Udklip af tekst fra case:

Johanne vil gerne have hjælp til at komme ud af sengen, så du beder hende om at vende sig om på siden og støde fra med armen, så hun kan komme op og sidde på sengekanten. Da hun sidder på sengekanten, klager hun over, at hun bliver svimmel. Samtidig får hun et hosteanfald og hoster rigeligt med sejt sekret op. Du giver hende et stykke cellestof til expectorat.

Tekst fra case er med udgangspunkt i problembaseret læring som metode og vægt på problemløsning i praksis analyseret og indsat i skabelon, der viser design af interaktive elementer: 

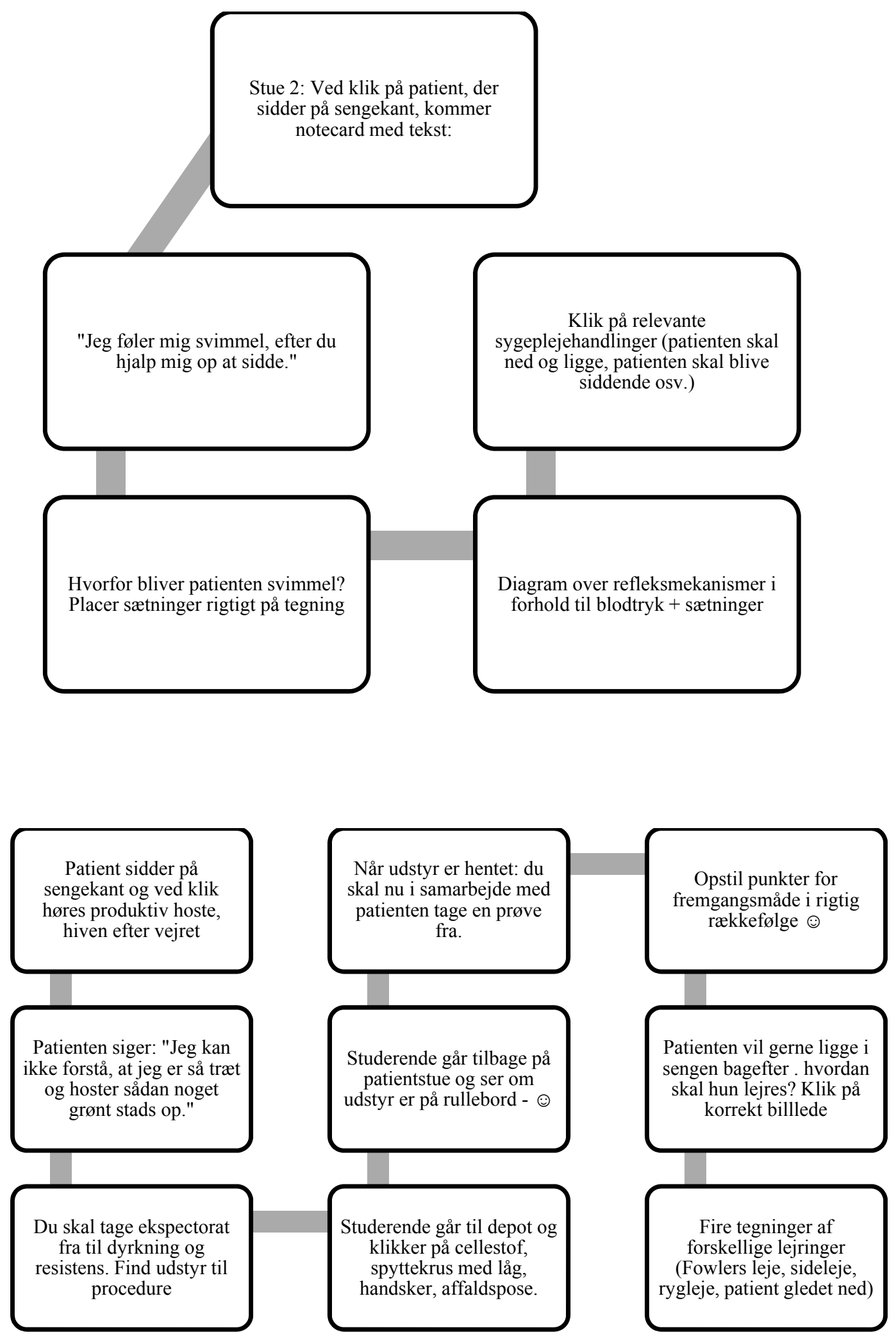
Principperne for designet af de interaktive elementer tager udgangspunkt i undersøgelser af, hvordan sygeplejestuderende lærer sygepleje i praksis, hvor tilegnelse af færdigheder i form af procedurer er vigtige sammenholdt med observationer af patienten(Nielsen, 2007).

De interaktive elementer består derfor af billeder, tekst og lyd, således læringsmiljøet er sammensat af visuelle, auditive, taktile, kinæstetiske og verbaliserede elementer. De studerende kan øve procedurer, hvor rækkefølgen har betydning i forhold til at overholde f.eks. hygiejniske principper og de kan på billeder observere patientens hud og ved lyd høre, hvordan patientens hoste er.

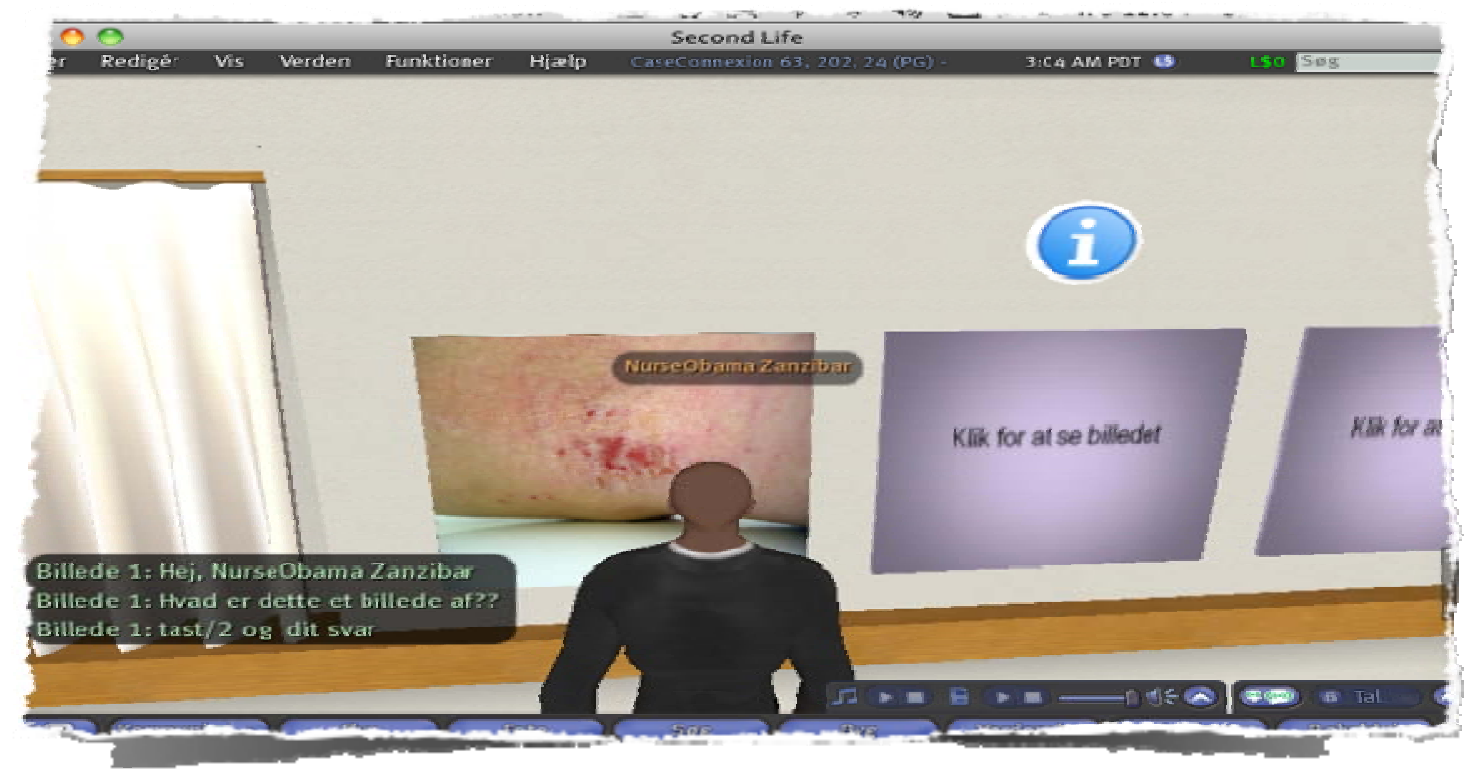

I forbindelse med udviklingen har det været vigtigt med meget konkrete overvejelser i forhold til, hvad der uden for stort besvær rent teknisk kan opbygges af interaktivitet i Second Life og hvordan interaktiviteten ikke styrer de sygeplejestuderende, så principperne i problembaseret læring mistes.

Hvis interaktiviteten giver de studerende svaret i form af f.eks. tre punkter, som de kan klikke på, vækker problemstillingen ikke undren og danner derfor ikke udgangspunkt for forhold, der behøver nærmere udredning, belysning og forståelse. De interaktive elementer veksler derfor mellem opgaver, hvor de studerende har svarene i form af sætninger, men hvor sætningerne så skal placeres i korrekt rækkefølge og opgaver, hvor de selv skal formulere svaret. 


\section{Afprøvning af virtuelt læringsmiljø i undervisningskontekst}

Det omtalte læringsmiljø opfattes som et pilotprojekt og de indhentede resultater kommer til at danne udgangspunkt for en konkret vurdering af, om virtuelle læringsmiljøer på det sygeplejefaglige område indeholder et læringspotentiale, der skal udbygges, hvorfor introduktion og afprøvning af miljøet samt evaluering af de konkrete resultater spiller en helt central rolle i det videre projektforløb.

Det virtuelle læringsmiljø skal ses som et supplement til den allerede eksisterende undervisning og som en del af de varierede studieformer, som sygeplejerskeuddannelsen består af. Læringsmiljøet skal derfor anvendes i et samarbejde mellem undervisere og studerende, hvorfor der også er lagt op til, at de studerende kan reflektere og søge vejledning hos den tilknyttede underviser, der også vil være til stede i Second Life. En afprøvning og efterfølgende evaluering indeholder derfor mulighed for at se, hvorvidt cases i et virtuelt læringsmiljø kan give sygeplejestuderende mulighed for at arbejde kundskabsbaseret og problemorienteret og om det som studieform understøtter de enkelte studerendes læringsstile. Et andet omdrejningspunkt bliver en vurdering af om et virtuelt læringsmiljø som studieform kan anvendes og integreres på alle uddannelsens niveauer.

\section{Forberedelse af undervisere og studerende}

Den første forudsætning for, at afprøvningen kan gennemføres med succes er dog, at de tekniske udstyr på uddannelserne kan håndtere Second Life. De nødvendige porte i netværket skal være åbne og computerne skal have standard grafik- og netkort. Det er vigtigt, at der er fokus på dette, da oplevelsen af ikke at kunne komme på Second Life de første gange, man prøver, kan ødelægge motivationen.

Dernæst skal de undervisere, der bruger Second Life i undervisningen have introduktion til, hvordan Second Life fungerer. Erfaringsmæssigt har Second Life har en stejl indlæringslæringskurve i starten. At agere i en 3Dvirtuel verden er en ny og uvant for de fleste og det kræver grundig instruktion og support inden ibrugtagningen af læringsmiljøet for at sikre, at underviserne kan agere i miljøet tilstrækkelig sikkert og kompetent til, at de er trygge ved at agere i miljøet i en undervisningssammenhæng. Ligeledes er det vigtigt, at der er adgang til hurtig support i forbindelse med ibrugtagningen af læringsmiljøet i undervisningssammenhæng (Skiba, 2009, Schmidt, 2009).

Der er derfor afviklet 6 timers workshop i Second Life for de involverede undervisere samtidig med at der udvikles en brugervejledning specifikt til læringsmiljøet. 
På workshoppen blev underviserne ud fra på forhånd definerede opgaver instrueret i de grundlæggende funktioner, som det er nødvendigt at kende for at kunne agere nemt og sikkert i Second Life f.eks. navigationsfunktioner, oprettelse af venner og landmarks og funktioner knyttet til avatarens udseende.

Endvidere lærte underviserne at kommunikere på forskellige niveauer - til enkelte avatarer og til mindre eller større grupper og at uploade præsentationer på læringsmiljøets whiteboards.

I forhold til de studerende er der en lignende problematik. De introduceres derfor på lignende måde som underviserne gennem lektioner, der skemalægges.

Derudover vil der i forbindelse med ibrugtagningen af læringsmiljøet i undervsiningssituationen være adgang til hurtig og kvalificeret support.

Det lægges endvidere op til, at der i forbindelse med den konkrete brug af læringsmiljøet vil ske en udbredt sidemandsoplæring og videndeling, og denne vil blive understøttet af en konkret vidensopsamling i et dertil egnet medie.

\section{Konklusion}

Udviklingen af læringsmiljøet til Sygeplejerskeuddannelsen i UC Lillebælt, UC Vest og UC Syd har været en omfattende, men også meget afklarende proces, hvor pædagogiske/didaktiske hensyn og tekniske muligheder har skullet spille sammen om at opbygge et konsistent og udviklende læringsmiljø, der kan understøtte de sygeplejestuderendes teoretiske og praktiske læring og samtidig være let tilgængelig og i høj grad selvinstruerende. Principperne for designet af de interaktive elementer tager udgangspunkt i sygeplejepraksis - hvordan ser praksis ud og hvordan lærer sygeplejestuderende i praksis, så læringsmiljøet kan bidrage til anvendelse af faglige teorier og metoder til problemløsning? Disse principper kan givetvis overføres til andre professionsrettede uddannelser, hvorfor erfaringerne fra dette pilotprojekt videregives.

Den fremtidige afprøvning af miljøet i den konkrete undervisningssituation er næste skridt og vil givetvis betyde, at der skal ske justeringer i forhold til konkrete cases og funktionalitet, men vi forventer, at miljøet vil bidrage til at øge de studerendes læringsmuligheder som en del af de varierede studieformer på Sygeplejerskeuddannelsen. 


\section{Referencer:}

Andreasen, Lars Birch. (2002). Virtuelt samarbejde i en flydende modernitet. I: Uddannelse, læring og IT- 26 forskere og praktikere gør status på området. Undervisningsministeriet. s. 46-51

Bjørke, Gerd. (2003). Problembaseret læring. Gads Forlag.

Fullan M.. (1993). Change Forces. Probing the Depths of Educational Reform. London

Hansen M. (2008). Versatile, Immersive, Creative and Dynamic Virtual 3-D Healthcare Learning Environment. Journal of Medical Internet Research. Vol. 10. nr. 3

Hansen M. et al. (2009). The Potential of 3-D virtual Worlds in Professional Nursing Education. Studies in Health Technology and Informatics. Volume 146. s. 582-586

Kamel, Boulos et al. (2008). Web 3D for Public, Environmental and Occupational Health:Early Examples from Second Life. International Journal of Environmental Research and Public Health; 5 (4). s. 290-317

Lauridsen, Ole. (2007). Fokus på læring - om læringsstile i dagligdagen privat og professionelt. Akademisk Forlag

Linton, D.A.et al. (2008). Translating medical practice from the real to the virtual: adapting an existing clinical program to a virtual world. AMIA Annu. Symp. Proc., Washington, USA. s.384-388

Nichols A.A.. Renwanz-Boyle A. (2001). Strategies for successfully educating nurses in the 21st century. I: Chaska N.L. (red.) The nursing profession: tomorrow and beyond. Sage London. s. 188-197

Nielsen, C. et al. (2007). Model for at lære praktisk sygepleje. Sygeplejersken, nr. 17.

Polson R.G., Farmer E.S. (2002). Integrating the humanities in the education of health professionals: implications for search and retrieval of information. Nurse Education in Practice 2. s. 49-54

Qvortrup, Lars. (1998). Det hyperkomplekse samfund. 14 fortællinger om informationssamfundet. København

Region Syddanmark. (2009). Uddannelses- og læringsstrategi. Region Syddanmark

Schmidt B., Stewart S. (2009). Implementing the virtual reality learning environment: Second Life. Nurse Educator, Jul-Aug; 34(4). s.152-5

Sivan, Y. (2008). Real Virtual Worlds Defined: The Immense Potential of Merging 3D,

Community, Creation, and Commerce. J. Virtual Worlds Res, 1, s. 1-31 
Skiba, D. J. (2007). Nursing Education 2.0: Second Life. Nurse Education Perspect. 28. s.156-157

Skiba, D.J., Conners H.R., Jeffries P.R.. (2008). Information technologies and the transformation of nursing education. Nurs Outlook. 56(5). s. 225230

Skiba, D. J. (2009). Nursing education 2.0: a second look at Second Life. Nurse Education Perspect. Mar-Apr;30(2). s.129-31

Undervisningsministeriet (2008). Bekendtgørelse om uddannelsen til professionsbachelor i sygepleje. BEK nr. 29 af 24/01/2008

Undervisningsministeriet (2008). Bekendtgørelse om akkreditering og godkendelse af erhvervsakademiuddannelser og professionsuddannelser mv. BEK nr. 684 af 27/06/2008

Warren JJ, Brixey JJ. (2009). Second Life: not your conventional simulation. Stud Health Technol Inform. s. 146-843

Link til læringsmiljøet CaseConnexion i Second Life:

http://slurl.com/secondlife/CaseConnexion/52/154/24

Link til præsentation af CaseConnexion:

http://www.youtube.com/watch?v=kg4EzSgp9Nc 